\title{
Relation between telomerase activity, hTERT and telomere length for intracranial tumours
}

\author{
L. MAES ${ }^{1}$, L. VAN NESTE ${ }^{2}$, K. VAN DAMME ${ }^{1}$, J.P.O. KALALA ${ }^{3}$, \\ L. DE RIDDER ${ }^{1}$, S. BEKAERT ${ }^{2}$ and M. CORNELISSEN ${ }^{1}$
}

\begin{abstract}
${ }^{1}$ Department of Anatomy, Embryology, Histology and Medical Physics, Section of Histology, Ghent University, ${ }^{2}$ Laboratory for Biochemistry and Molecular Cytology, Department of Molecular Biotechnology, FLTBW-Ghent University and

${ }^{3}$ Department of Neurosurgery, University Hospital, De Pintelaan 185, B-9000 Ghent, Belgium
\end{abstract}

Received April 13, 2007; Accepted July 12, 2007

\begin{abstract}
Human linear chromosomes are capped by specialized DNA-protein structures called telomeres. The present study analysed the telomerase activity, hTERT protein and telomere length in meningiomas and gliomas in relation to their WHO grading. Fifty-three freshly dissected tumour biopsies were analysed for telomerase activity, hTERT protein expression and telomere length. Telomerase activity was examined in 41 of the 53 biopsies. Telomerase activity was detected in 3 of $35(8.6 \%)$ screened meningiomas (1 benign, 1 atypical and 1 malignant meningioma). For hTERT expression, $56.4 \%$ of meningiomas were positive with a mean labelling index (hTERT LI) of $31.3 \%(\mathrm{SD}=26.5)$ for the hTERT positive meningiomas. The mean telomere length for meningiomas was $6.983 \mathrm{~kb}(\mathrm{SD}=1.969)$. For gliomas, no active telomerase was detected in 2 low-grade astrocytomas, whereas three of the four screened glioblastomas were positive for telomerase activity. The only hTERT protein positive astrocytoma had a mean labelling index of 9.0\%. On the other hand, the hTERT LI for glioblastomas was $53.6 \%$ $(\mathrm{SD}=28.0)$. The two low-grade astrocytomas had a telomere length of 14.310 and $9.236 \mathrm{~kb}$. The anaplastic astrocytoma had a telomere length of $4.903 \mathrm{~kb}$ and the glioblastomas $5.767 \mathrm{~kb}(\mathrm{SD}=2.042)$. The normal meningeal and neuronal tissue is negative for telomerase activity and hTERT. The length was $\pm 10.000 \mathrm{~kb}$. These results indicate that telomere shortening may be a critical step in pathogenesis of atypical and malignant meningiomas and gliomas. Critical telomere shortening in vitro was shown to activate telomerase.
\end{abstract}

\section{Introduction}

Telomeres play an essential role in maintaining the stability and integrity of chromosomes $(1,2)$. They consist of TTAGGG

Correspondence to: Dr Lode Maes, Department of Anatomy, Embryology, Histology and Medical Physics, Section of Histology, Ghent University, De Pintelaan 185, B-9000 Gent, Belgium

E-mail: lode.maes@ugent.be

Key words: telomerase, telomere length, intracranial tumours tandem repeats (3). Telomeres gradually shorten with each cell division in vitro and telomere length is shown to decrease with age in vivo $(2,4)$. This shortening of telomeres may be a mitotic clock for cells leading to senescence and apoptosis $(5,6)$. Normal human cells shorten their telomeres until they reach a critical length $(\sim 4 \mathrm{~kb})$. In some instances, by chromosomal instability, cells escape from apoptosis leading to indefinite life span by activating telomerase $(7,8)$. Telomerase is a ribonucleoprotein enzyme complex that synthesizes telomeric repeats at the chromosomal ends (4). Two major components of the telomerase complex are hTERT (human telomerase reverse transcriptase) and an RNA template $(9,10)$. If tumour cells turn on telomerase, the expression of this enzyme may lead to unlimited proliferation and immortality for tumour cells (11). Some results have already been published on telomerase and telomeres in intracranial tumours (12-14), showing a correlation between telomerase activity and histopathological grading. It has been reported that hTERT rather than telomerase activity could be used as a prognostic marker for progression and potential recurrence (15-17). Moreover, hTERT could be considered as an early signal towards indefinite life span (18). Telomere length can be seen as the result of the interaction between active telomerase and the telomeric DNA ends (19). This length is crucial for the protection of the chromosomes (1). In our previous studies, we found a lack of telomerase activity and low hTERT-protein expression in benign meningiomas in comparison to malignant tumours $(18,20)$. In the present study, we examined the telomerase activity, the hTERT protein expression and the telomere length in intracranial tumours to see if there is any difference between benign, malignant and normal intracranial tissue and if tumours without telomerase activity also have attritions or aberrations in their telomere length.

\section{Materials and methods}

Surgical specimen. Biopsies of 53 intracranial tumours including 39 meningiomas [34 WHO (World Health Organization) grade I meningiomas, 3 atypical WHO grade II meningiomas and 2 malignant WHO grade III meningiomas] and 14 gliomas (2 low-grade WHO grade II astrocytomas, 1 anaplastic WHO grade III astrocytoma and 11 WHO grade 
IV glioblastoma multiforme) were collected from the University Hospital, St. Lucas Hospital and Maria-Middelares, Ghent, Belgium. There were 34 women and 19 men with a median age of 56.7 (range 31-81). The classification and grading of the tumours was performed by the pathologists based on the WHO criteria (21). Immediately after surgery, the tumour fragments were transferred into vials containing Minimal Essential Medium (MEM, Invitrogen, Merelbeke, Belgium) for transport. One part was used for histopathological diagnosis and a second part was conserved in liquid nitrogen for molecular analysis of telomerase activity and measurement of telomere length. This research was approved by the Ethics Committee of Ghent University, Belgium (project 2001/58).

Detection of telomerase activity. For telomerase activity analysis, the surgical specimens were immediately frozen in liquid nitrogen and stored until use. Protein extracts were prepared from frozen samples in 100-250 $\mu 1$ ice-cold extraction buffer [10 mM Tris- $\mathrm{HCl}(\mathrm{pH} 7.5), 1 \mathrm{mM} \mathrm{MgCl}{ }_{2}$, $1 \mathrm{mM}$ ethylene glycol tertraacetic acid (EGTA), $0.1 \mathrm{mM}$ benzamidine, 0.5\% CHAPS, $5 \mathrm{mM}$ ß-mercaptoethanol, $10 \%$ glycerol], depending on the size of tumour sample. After 30 min incubation on ice, lysates were centrifuged at $13500 \mathrm{rpm}$ for $20 \mathrm{~min}$ at $4^{\circ} \mathrm{C}$, and 60-200 $\mu 1$ from each supernatant was collected. Protein content in each lysate was measured using the Bradford assay (Bio-Rad Laboratories, Nazareth Eke, Belgium) and adjusted to $600 \mathrm{ng} / \mu 1$. Aliquots of $40 \mu \mathrm{l}$ protein extracts were frozen in liquid nitrogen. Telomerase enzymatic activity was determined using the Telomeric Repeat Amplification Protocol (TRAP) of the TRAPeze Telomerase Detection Kit (Chemicon, Heule, Belgium). Briefly, $1.2 \mu \mathrm{g}$ protein extract was incubated in $50 \mu 1$ reaction mixture containing $5 \mu 1$ 10X TRAP reaction buffer, $1 \mu 1$ 50X dNTP Mix, $1 \mu 1$ TS primer (5'-AATCCGTC GAGCAGAGTT-3'), $1 \mu 1$ Primer Mix (RP primer 5'-GCGC GG[CTTACC $]_{3}$ CTAACC-3', K1 primer and TSK1 template for internal control), and 2 units TaqDNA polymerase at $30^{\circ} \mathrm{C}$ for $30 \mathrm{~min}$ for telomerase-mediated extension of the TS primers. Reaction mixtures were subjected to 30 cycles using the following conditions: $94^{\circ} \mathrm{C}$ for $30 \mathrm{sec}, 59^{\circ} \mathrm{C}$ for $30 \mathrm{sec}$ and $72^{\circ} \mathrm{C}$ for $30 \mathrm{sec}$. Twenty-five microliters of each polymerase chain reaction (PCR) sample was analysed by electrophoresis on $10 \%$ polyacrylamide-urea gels and visualized with SYBR-Green I nucleic acid gel stain by means of an ultraviolet (UV) transilluminator. Telomerase activity is defined as an incremental ladder. The inclusion of an internal control, a synthetic DNA construct added to the samples and which is amplified with the TS and RP primers to generate a 36-bp product, aided the detection of false negatives, which can be the result from the presence of PCR inhibitors in the extracts. An immortal cell line derived from a glioblastoma multiforme showed telomerase activity and was used as positive control. As negative control lysis buffer replaced cDNA.

Immunohistochemical evaluation for hTERT. Paraffinembedded tissue sections $(4-\mu \mathrm{m})$ from intracranial meningiomas were prepared for examination by immunohistochemical procedures. Slides were heated in sodium citrate

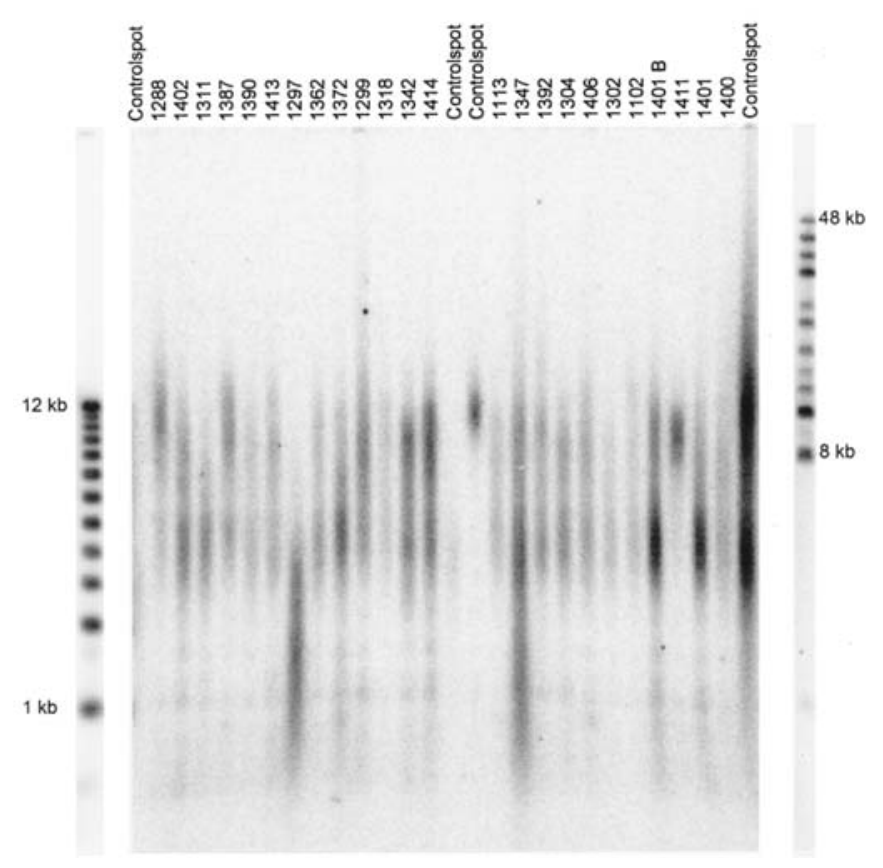

Figure 1. A blot after hybridisation with a telomere specific probe. The first and last lanes are DNA markers applied for molecular weight calibration [left, low molecular weight marker (LMW, 1-12 kb); right, high molecular weight marker (HMW, 8-48 kb)]. Average telomere length from a lysis of tumour cells is measured as mean telomere length (23).

buffer (10 mM, pH 6.0) for $30 \mathrm{~min}$ in a microwave oven at the highest power (700 W, Amana, Newton, IA, USA) for high temperature antigen unmasking. The endogenous peroxidase activity was blocked by $3 \% \mathrm{H}_{2} \mathrm{O}_{2}$ (Eurolab, Leuven, Belgium) in distilled water for $10 \mathrm{~min}$ at room temperature. The standard streptavidin-biotin-peroxidase complex method was performed, employing antibodies against hTERT (1:50 dilution; clone 44F12; Novocastra, Newcastle upon Tyne, UK). hTERT expression was defined as the ratio of cells with immunoreactivity for 1000 tumour cells for biopsies and as positive/negative for cultures. Subsequently, samples were incubated with biotinylated rabbit anti-mouse, 1:200 for $30 \mathrm{~min}$, followed by the third incubation with streptavidinbiotin-peroxidase complex, 1:200 for $30 \mathrm{~min}$. Visualization of the complex was realized with diaminobenzidine (DAB) and sections were counterstained with haematoxylin. A glioblastoma multiforme, positive for hTERT, was used as positive control, whereas normal brain tissue and antigen-free buffer of the positive control as a negative control. hTERT percentages were calculated as mean percentage values by counting nuclei of tumour cells in three positive areas of a single tumour for thousand cells.

Telomere length analysis (Fig. 1). We followed standard methodology for telomeres sizing (22-24). Genomic DNA was double digested with respectively $5 \mathrm{U} R s a \mathrm{I}$ and $10 \mathrm{U}$ HinfI for $>3 \mathrm{~h}$ at $37^{\circ} \mathrm{C}$ and subsequently fragmented by Field Inversion Gel Electrophoresis (between 1 and $25 \mathrm{~kb}$ ) on a $1 \%$ agarose gel. Samples were analysed in triplicate. Fractionated DNA was immobilized on positively charged nylon membranes after denaturation and neutralization. Southern blots were simultaneously hybridised overnight at $42^{\circ} \mathrm{C}$ with a P32 
Table I. Telomerase activity, hTERT protein expression and telomere length in intracranial tumours ( 34 benign, 3 atypical and 2 malignant meningiomas; 2 low-grade and 1 anaplastic astrocytoma; 11 glioblastoma multiforme).

$\begin{array}{cccc} & & \text { hTERT } & \\ & \text { Telomerase } & \text { labeling } & \text { Telomerase } \\ \text { No. } & \text { activity } & \text { index }(\%) & \text { length }(\mathrm{kb})\end{array}$

Benign meningiomas (WHO grade I)

2

3

4

5

6

7

8

9

10

11

12

13

14

15

16

17

18

19

20

21

22

23

24

25

26

\begin{tabular}{|c|c|}
\hline $\mathrm{Neg}$ & 0.0 \\
\hline $\mathrm{Neg}$ & 0.8 \\
\hline Neg & 0.0 \\
\hline $\mathrm{Neg}$ & 0.0 \\
\hline Pos & 11.9 \\
\hline Neg & 0.0 \\
\hline Neg & 0.0 \\
\hline $\mathrm{Neg}$ & 29.6 \\
\hline Neg & 0.0 \\
\hline $\mathrm{Neg}$ & 28 \\
\hline- & 72.7 \\
\hline Neg & 1.1 \\
\hline- & 76.2 \\
\hline $\mathrm{Neg}$ & 0.0 \\
\hline - & 8.3 \\
\hline $\mathrm{Neg}$ & 47.1 \\
\hline- & 72.3 \\
\hline $\mathrm{Neg}$ & 56.6 \\
\hline $\mathrm{Neg}$ & 60.6 \\
\hline $\mathrm{Neg}$ & 0.0 \\
\hline $\mathrm{Neg}$ & 0.0 \\
\hline Neg & 8.0 \\
\hline Neg & 0.0 \\
\hline $\mathrm{Neg}$ & 0.0 \\
\hline $\mathrm{Neg}$ & 0.0 \\
\hline $\mathrm{Neg}$ & 0.0 \\
\hline $\mathrm{Neg}$ & 0.0 \\
\hline Neg & 21.6 \\
\hline $\mathrm{Neg}$ & 13.1 \\
\hline Neg & 9.1 \\
\hline Neg & 2.2 \\
\hline $\mathrm{Neg}$ & 0.0 \\
\hline $\mathrm{Neg}$ & 0.0 \\
\hline Neg & 0.0 \\
\hline \multicolumn{2}{|c|}{ typical meningioma (WHO grade II) } \\
\hline $\mathrm{Neg}$ & 25.6 \\
\hline Neg & 0.6 \\
\hline Pos & 52.1 \\
\hline
\end{tabular}

6.972

6.716

8.749

8.592

7.911

8.031

6.006

7.444

4.794

5.329

14.019

5.055

9.278

6.701

7.779

5.989

7.361

6.720

6.258

6.900

7.321

7.635

6.222

3.694

5.852

7.270

8.163

5.764

7.977

6.062

6.846

8.046

8.489

7.653

4.469

4.807

6.532

Malignant meningioma (WHO grade III)

$\begin{array}{lll}\text { Neg } & 26.4 & 9.772 \\ \text { Pos } & 64.5 & \mathbf{3 . 1 7 1}\end{array}$

Astrocytoma LG (WHO grade II)

$\begin{array}{llc}\text { Neg } & 0.0 & 14.31 \\ \mathrm{Neg} & 9.0 & 9.236\end{array}$

Table I. Continued.

\begin{tabular}{|c|c|c|c|}
\hline No. & $\begin{array}{c}\text { Telomerase } \\
\text { activity }\end{array}$ & $\begin{array}{c}\text { hTERT } \\
\text { labeling } \\
\text { index }(\%)\end{array}$ & $\begin{array}{l}\text { Telomerase } \\
\text { length }(\mathrm{kb})\end{array}$ \\
\hline \multicolumn{4}{|c|}{ Anaplastic astrocytoma (WHO grade III) } \\
\hline 42 & - & 0.3 & 4.903 \\
\hline \multicolumn{4}{|c|}{ Glioblastoma multiforme (WHO grade IV) } \\
\hline 43 & Neg & 70.0 & 4.703 \\
\hline 44 & Pos & 60.0 & 6.826 \\
\hline 45 & Pos & 49.0 & 7.843 \\
\hline 46 & Pos & 88.6 & 5.079 \\
\hline 47 & - & 73.6 & 3.415 \\
\hline 48 & - & 19.3 & 6.523 \\
\hline 49 & - & 9.2 & 8.326 \\
\hline 50 & - & 62.0 & 4.269 \\
\hline 51 & - & 10.7 & 2.539 \\
\hline 52 & - & 78.2 & 5.149 \\
\hline 53 & - & 68.7 & 8.764 \\
\hline
\end{tabular}

Telomere length in normal intracranial tissue $(\mathrm{kb})$

$\begin{array}{lrr}\text { Meninges } & 11.3090 & 9.7589 \\ \text { Brain tissue } & 8.833 & 10.074 \\ & 11.801 & 9.697\end{array}$

Neg, negative; Pos, positive; -, not available.

radiolabelled 5-mer synthetic oligonucleotide telomeric probe and radiolabelled high (8-48 kb) and low (1-12 kb) molecular weight DNA markers (Invitrogen). Corresponding molecular weights were calculated on the basis of DNA marker calibration curve.

Statistical analysis. All statistical analysis was carried out using SPSS for windows version 12.0 (SPSS Inc., Chicago, IL, USA). The categorized variables entered into the analysis were patients' histological subtype, telomerase activity, hTERT protein expression and telomere length. A Mann-Whitney test was used to analyse the association between histo-pathological grading, telomerase activity, hTERT protein expression and telomere length. The level of significance was set at $\mathrm{p}<0.05$.

\section{Results}

A general presentation for the results concerning telomerase activity, hTERT protein expression and telomere length is given in Table I. There were 53 intracranial tumours (34 benign meningiomas, 3 atypical meningiomas, 2 malignant meningiomas, 2 low-grade astrocytomas, 1 anaplastic astrocytoma and 11 glioblastomas).

Telomerase activity (Table I). Forty-one cases of intracranial tumours (30 benign, 3 atypical and 2 malignant meningiomas; 2 low-grade astrocytomas and 4 glioblastomas) were analysed 


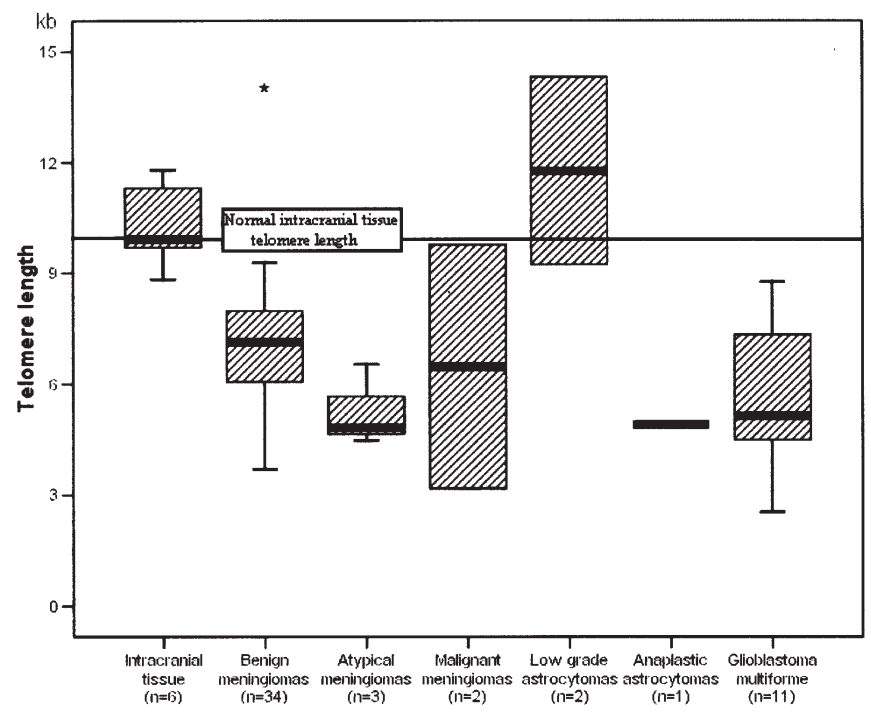

Figure 2. Telomere length in 53 intracranial tumours compared with normal intracranial tissue. Telomere length was determined by Southern blotting. The mean distribution of the different tumour types for telomere length lies under normal intracranial tissue with the exception of low-grade astrocytomas.

for telomerase activity. Telomerase activity was not examined for 12 of the 53 cases because no part of the biopsy was stored in the liquid nitrogen. Overall, telomerase activity was detected in 6 of 41 tumours $(14.6 \%)$. One of $30(0.03 \%)$ benign meningiomas, 1 of $3(33.3 \%)$ atypical meningiomas and 1 of $2(50 \%)$ malignant meningiomas expressed telomerase activity. Within the group of gliomas, neither 1 of the 2 low-grade astrocytomas and 3 of 4 screened glioblastomas possessed active telomerase. The number and percentage of intracranial tumours with telomerase activity increased in the higher histopathological grades. Thus, telomerase activity strongly correlated $(\mathrm{P}<0.001)$ with the histopathological grading of the tumours by the WHO-classification.

Detection of hTERT-protein. The hTERT labelling indices for all intracranial tumour samples are presented in Table I. hTERT protein staining was seen in the nucleolar region of tumour cells. Heterogeneity and intensity of hTERT staining varied depending on the tumour. Positive cells were clustered together surrounded with non-stained cells. Twenty-two of $39(56.4 \%)$ meningiomas were positive for the 44F12 antibody against hTERT. Within this group, there were 17 of 34 (50\%) benign meningiomas, the $3(100 \%)$ atypical meningiomas and all (100\%) malignant meningiomas. The mean hTERT labelling index (LI) for all 22 hTERT positive meningiomas was $31.3 \%$ ( $\mathrm{SD}=26.5$ ). The mean hTERT LI for the 17 benign hTERT positive meningiomas was $30.5 \%$ ( $\mathrm{SD}=27.6)$. The atypical meningiomas had a mean hTERT LI of $26.1 \%(\mathrm{SD}=25.7)$ and the malignant meningiomas $45.5 \%$ $(\mathrm{SD}=26.9)$

One of 2 low-grade astrocytomas was positive for hTERT with $9 \%$ of tumour cells labelled. The anaplastic astrocytoma had an hTERT expression of $0.3 \%$ of the tumour cells. All the glioblastomas were positive for hTERT and the mean hTERT LI was 53.6\% $(\mathrm{SD}=28.0)$. The difference for
hTERT staining between hTERT positive benign meningiomas and glioblastomas is statistically significant $(\mathrm{P}<0.05)$.

Telomere length measurement (Table I and Figs. 1 and 2). Telomere length appears as a smear on a Southern blot gel because the amount of TTAGGG repeats at the (sub)telomeric regions varies on the different chromosomes and the different cells. Also, the telomere length varies from cell to cell within a tumour.

We analysed the mean telomere length of 53 tumour biopsies of intracranial tumours. Also samples of meningeal and brain tissue from fresh corpses were analysed. These samples were collected from the Anatomical department of the university and included brain tissue and meninges. Samples were analysed twice to verify our results.

The mean telomere length of intracranial tissue from healthy persons was $10.245 \mathrm{~kb}(\mathrm{SD}=1.11)$. This mean length was $10.534 \mathrm{~kb}(\mathrm{SD}=1.096)$ for the meninges, $10.316 \mathrm{~kb}$ $(\mathrm{SD}=2.099)$ for grey matter and $9.885 \mathrm{~kb}(\mathrm{SD}=0.266)$ for white matter.

The mean telomere length for the 39 meningiomas was $6.983 \mathrm{~kb}(\mathrm{SD}=1.869)$. For the 34 benign meningiomas, we found a mean length of $7.165 \mathrm{~kb}(\mathrm{SD}=1.724)$. The mean telomere length for the 3 atypical meningiomas was $5.269 \mathrm{~kb}$ $(\mathrm{SD}=1.107)$ and $6.472 \mathrm{~kb}(\mathrm{SD}=4.668)$ for the malignant meningiomas.

For the low-grade astrocytomas, in one of the samples a mean telomere length was measured of $14.310 \mathrm{~kb}$, while the telomere length for the other was $9.236 \mathrm{~kb}$. The anaplastic astrocytoma had a mean length of $4.903 \mathrm{~kb}$. For the 11 glioblastomas the mean telomere length was $5.767 \mathrm{~kb}$ $(\mathrm{SD}=2.042)$.

The telomere length was significantly shorter for the group of meningiomas and gliomas $(\mathrm{P}<0.001)$, in comparison to the normal intracranial tissue, with the exception of one low-grade astrocytoma.

\section{Discussion}

In telomerase positive cells telomere length is balanced by telomere shortening due to cell division and telomere elongation by telomerase. In mortal cells, telomeres shorten during proliferation and hence can be considered as a marker for the replicative capacity of cells in vitro (22). This capacity keeps tumour cells proliferating and growing by the stabilization of their telomeres which is essential to maintain the unlimited dividing potential and to escape 'crisis' (25). At crisis, the telomeres are at critical length, and the integrity of the chromosomes declines with every subsequent cell division. Telomere length is maintained by telomerase activity and can be influenced in different ways and by various factors (26). From literature it is clear that telomerase activity can be regarded as a prognostic marker for malignancy $(12,13,16)$. In contrast to malignant intracranial tumours, benign meningiomas seldom express telomerase activity.

As telomeres are essential for DNA replication and control of cell division (1), the regulation of their length has been a focus of research on tumourigenesis $(13,14)$. It has been demonstrated that telomere shortening, which occurs at every successive cell division in somatic cells, is stopped in most tumours, which leads to immortalisation through the 
activation of telomerase. The presence of telomerase activity indicates the capacity for unlimited cell proliferation (27).

In this study, we investigated the possible link between telomerase activity, hTERT expression and telomere length in intracranial tumours. The specificity for immunostaining against hTERT has been criticized although the sensitivity posed no problems (28). For them NCL-hTERT was a marker for nucleolin. Although, hTERT and nucleolin share the same intracellular distribution and their nucleolin demonstrates another molecular weight than that found by others.

We found a significant shortening of the telomeres in the group of meningiomas and gliomas as compared with normal intracranial tissue. Fig. 2 represents the attrition of telomeres for the different groups of tumours. A shortening is visible for the meningiomas in comparison to normal meninges. Moreover, a clear shortening is visible for the glioblastomas as compared to normal intracranial tissue and benign meningiomas. Cells from highly proliferating tumours such as glioblastomas present higher mitotic activity than benign slow proliferating tumours. As a result, the telomere will shorten quicker in glioblastomas than in benign meningiomas. A high expression of hTERT implies that telomeres could be stabilized or elongated by active telomerase. All glioblastomas expressed hTERT and $75 \%$ of the analysed samples had active telomerase. Only half of the benign meningiomas expressed hTERT and the labelling indexes were lower than the group of gliomas. Telomere ends of tumour cells from benign meningiomas shorten at ease because of their slower growth. The 'crisis' situation is leading to apoptosis $(5,6)$. Only one benign meningioma had active telomerase $(0.03 \%)$. Because the three atypical meningiomas had shorter telomeres than the benign meningioma, they seem to be in a further state of progression with higher proliferation and mitosis. hTERT was detected in all three atypical meningiomas and one had active telomerase. One of two malignant meningiomas had active telomerase and both expressed hTERT. The malignant meningioma with active telomerase had remarkable short telomeres as compared to normal intracranial tissue and the benign meningiomas. Chen et al hypothesized that telomerase activity can be regulated and temporary turned-off, as the telomeres are longer again (13). In our study, we found longer telomeres in one of the two low-grade astrocytomas. One of the lengths was even longer than the normal intracranial tissue. This was remarkable because there was no expression of hTERT or active telomerase. Our findings support the hypothesis that sufficient (hTERT-mediated) telomere stabilization is achieved late in tumourigenesis after extensive cell proliferation and telomere shortening has already taken place (29). In this respect, telomere maintenance or even elongation seem to be essential for the tumour to maintain its (indefinite) proliferative capacity and to continue further tumour progression and invasion $(1,26)$. In normal somatic cells, when telomeres become critically shortened, these enter a growth arrest state. Longer telomeres provide the cell more mitotic potential. It is supposed that there is a mechanism that regulates telomerase activity and telomere length $(30,31)$. When the length is long enough for proliferation, telomerase activity subsides. Because glioblastomas are high proliferating tumours, they keep their telomere length steady with active telomerase. Telomerase and telomere length serve as indicators for the ability of each tumour to compensate for replicative telomere losses $(32,33)$.

The anaplastic astrocytoma had short telomeres but hardly any expression of hTERT. This tumour could be in a further state of progression leading to active telomerase towards a classification of a secondary glioblastoma multiforme. Expression of hTERT does not mean activation of the telomerase complex but is one of the crucial steps towards the activation (17). Hiyama et al found a correlation between the length of telomeres and the prognosis in medulloblastomas (34). The author concluded that short telomeres are linked to a further state of progression and a more aggressive behaviour for these tumours. Also other studies on telomere length for intracranial tumours found a shortening of the telomeres for telomerase positive tumours $(14,35)$. In our study, most tumours $(96 \%)$ had shorter telomeres compared to normal intracranial tissue. Shorter telomeres in cancer tissue compared to normal tissue are indicative for extensive tumour cell proliferation. However, telomere stabilization by telomerase is inevitable at a critical point of telomere shortening to prevent the onset of crisis and senescence (26).

These results indicate that telomerase activation may be a critical step in the pathogenesis of gliomas and meningiomas. Shortening of the telomere length also indicates a high potential for malignant behaviour in these tumours. In our series, telomerase activity was detected in 2 of 5 specimens $(40 \%)$ of atypical and malignant meningiomas. Compared to benign meningiomas, 1 out of 30 cases was positive for telomerase activity, this difference speaks for a late activation of telomerase in tumour progression.

Detectable telomerase activity and shortened telomere length are clinically relevant because the presence of these factors may suggest that the tumours contain a population of cells with the capacity for unlimited proliferation (13).

Telomere length was reduced in the high-grade tumours, whereas it was compatible with that of normal brain tissues in the low-grade astrocytomas, suggesting that telomerase activity with shortened telomeres correlates with the aggressive growth of high-grade intracranial tumours.

We conclude that telomere length cannot be used as a putative prognostic marker on its own but should be linked with hTERT expression and telomerase activity. There are signs for alternative mechanisms of telomere elongation (cases 11 and 40 in Table I), although most tumours have critically shortened telomeres.

These findings suggests that telomerase activity and hTERT, together with the telomere length can be an index of malignant potential or malignancy itself in intracranial tumours.

\section{Acknowledgements}

We would like to thank the neurosurgeons from the University Hospital, St. Lucas Hospital and Maria-Middelares in Ghent, who kindly provided us with tumour samples, and N. François, R. De Vos, L. Pieters and J. Aernoudt from our laboratory for technical assistance. 


\section{References}

1. Blackburn EH and Szostak JW: The molecular structure of centromeres and telomeres (review). Annu Rev Biochem 53: 163-164, 1984

2. Blackburn EH: Structure and function of telomeres. Nature 350: 569-573, 1991.

3. Moyzis RK, Buckingham JM, Cram LS, Dani M, Deaven LL, Jones MD, Meyne J, Ratliff RL and WU JR: A highly conserved repetitive DNA sequence (TTAGGG)n present at the telomeres of human chromosomes. Proc Natl Acad Sci USA 85: 6622-6626, 1988.

4. Nugent CI and Lundblad V: The telomerase reverse transcriptase: components and regulation. Genes Dev 12: 1073-1085, 1998.

5. Cong YS, Wright WE and Shay JW: Human telomerase and its regulation (review). Microbiol Mol Biol Rev 66: 407-425, 2002.

6. Hahn WC: Role of telomeres and telomerase in the pathogenesis of human cancer (review). J Clin Oncol 2: 2034-2043, 2003.

7. Maser RS and De Pinho RA: Connecting chromosomes, crisis and cancer. Science 297: 565-569, 2002.

8. Ulaner GA: Telomere maintenance in clinical medicine (review). Am J Med 117: 262-269, 2004.

9. Masutomi K, Kaneko S, Hayashi N, Yamashita T, Shirota Y, Kobayashi $\mathrm{K}$ and Murakami S: Telomerase activity reconstituted in vitro with purified human reverse transcriptase and human telomerase RNA component. J Biol Chem 274: 22568-22573, 2000.

10. Weinrich SL, Pruzan R, Ma L, Ouellette M, Tesmer VM, Holt SE, Bodnar AG, Lichtsteiner S, Kim NW, Trager JB, Taylor RD, Carlos R, Andrews WH, Wright WE, Shay JW, Harley CB and Morin GB: Reconstitution of human telomerase with the template RNA component hTR and the catalytic protein subunit hTRT. Nat Genet 17: 498-502, 1997

11. Kim NW, Piatyszek MA, Prowse KR, Harley CB, West MD Ho PL, Coviello GM, Wright WE, Weinrich SL and Shay JW: Specific association of human telomerase activity with immortal cells and cancer. Science 266: 2011-2015, 1994

12. Boldrini L, Pistolesi S, Gisfredi S, Ursino S, Lupi G, Caniglia M, Pingitori R, Basolo F, Parenti G and Fontanini G: Telomerase in intracranial meningiomas. Int J Mol Med 12: 943-947, 2003.

13. Chen HJ, Liang CL, Lu K, Lin JW and Cho CL: Implication of telomerase activity and alternations of telomere length in the histologic characteristics of intracranial meningiomas. Cancer 89: 2092-2098, 2000

14. Morii K, Tanaka R, Onda K, Tsumanuma I and Yoshimura J: Expression of telomerase RNA, telomerase activity, and telomere length in human gliomas. Biochem Biophys Res Commun 239: 830-834, 1997.

15. Falchetti ML, Larocca LM and Pallini R: Telomerase in brain tumours (review). Childs Nerv Syst 18: 112-117, 2002.

16. Maes L, Lippens E, Kalala JP and De Ridder L: The hTERTprotein and Ki-67 labelling index in recurrent and non-recurrent meningiomas. Cell Prolif 38: 3-12, 2005

17. Simon M, Park TW, Leuenroth S, Hans VH, Loning T and Schramm J: Telomerase activity and expression of the telomerase catalytic subunit, hTERT, in meningioma progression. J Neurosurg 92: 832-840, 2000 .

18. Maes L, Kalala JP, Cornelissen R and De Ridder L: Telomerase activity and hTERT protein expression in meningiomas: an analysis in vivo versus in vitro. Anticancer Res 26: 2295-2300, 2006.

19. Morin GB: The human telomere terminal transferase enzyme is a ribonucleoprotein that synthesizes TTAGGG repeats. Cell 59: 521-529, 1989.

20. Kalala JP, Maes L, Vandenbroecke C and De Ridder L: The hTERT protein as a marker for malignancy in meningiomas. Oncol Rep 13: 273-277, 2005.
21. Kleihues P and Cavenee WK: Pathology and genetics of the nervous system. In: World Health Organization Classification of Tumours. Kleihues P and Cavenee WK (eds). IARC Press, Lyon, 2000.

22. Allsopp RC, Vaziri H, Patterson C, Goldstein S, Younglai EV Futcher AB, Greider CW and Harley CB: Telomere length predicts replicative capacity of human fibroblasts. Proc Nat Acad Sci USA 89: 10114-10118, 1992.

23. Bekaert S, van Pottelbergh I, De Meyer T, Zmierczak H, Kaufman JM, van Oostveldt P and Goemaere S: Telomere length versus hormonal and one mineral status in healthy elderly men. Mech Ageing Dev 126: 1115-1122, 2005.

24. Cerezo A, Stark HJ, Moshir S and Boukamp P: Constitutive overexpression of human telomerase reverse transcriptase but not c-myc blocks terminal differentiation in human HaCaT skin keratinocytes. J Invest Dermatol 121: 110-119, 2003.

25. Hahn WC and Weinberg RA: Rules for making human tumour cells (review). N Engl J Med 347: 1593-1603, 2002.

26. Gertler R, Rosenberg R, Stricker D, Friederichs S, Hoos A, Werner M, Ulm K, Holzmann B, Nekarda H and Siewert JR: Telomere length and human telomerase reverse transcriptase expression as markers for progression and prognosis of colorectal carcinoma. J Clin Oncol 22: 1807-1814, 2004

27. Counter CM, Avilion AA, Le Feuvre CE, Stewart NG Greider CW, Harley CB and Bacchetti S: Telomere shortening associated with chromosome instability is arrested in immortal cells which express telomerase activity. EMBO J 11: 1921-1929 1992

28. Wu YL, Dudognon C, Nguyen E, Hillion J, Pendino F, Tarkanyi I, Aradi J, Lanotte M, Tong JH, Chen GQ and SegalBendirdjian E: Immunodetection of human telomerase reverse transcriptase (hTERT) re-appraised: nucleolin and telomerase cross paths. J Cell Sci 119: 2797-2806, 2006.

29. Engelhardt M, Drullinsky P, Guillem J and Moore MA Telomerase and telomere length in the development and progression of premalignant lesions to colorectal cancer. Clin Cancer Res 3: 1931-1941, 1997.

30. Jiang WQ, Zhong ZH, Henson JD, Neumann AA, Chang AC and Reddel RR: Suppression of alternative lengthening of telomeres by Sp100-mediated sequestration of the MRE11/ RAD50/NBS1 complex. Mol Cell Biol 25: 2708-2721, 2005.

31. Muntoni A and Reddel RR: The first molecular details of ALT in human tumour cells (review). Hum Mol Genet 14: R191-R196, 2005.

32. Hakin-Smith V, Jellinek DA, Levy D, Carroll T, Teo M, Timperley WR, McKay MJ, Reddel RR and Royds JA: Alternative lengthening of telomeres and survival in patients with glioblastoma multiforme. Lancet 361: 836-838, 2003.

33. Henson JD, Hannay JA, McCarthy SW, Royds JA, Yeager TR, Robinson RA, Wharton SB, Jellinek DA, Arbuckle SM, Robinson BG, Learoyd DL, Stalley PD, Bonar SF, Yu D, Pollock RE and Reddel RR: A robust assay for alternative lengthening of telomeres in tumours shows the significance of alternative lengthening of telomeres in sarcomas and astrocytomas. Clin Cancer Res 11: 217-225, 2005.

34. Hiyama E, Hiyama K, Yokoyama T, Ichikawa T and Matsuura Y Length of telomeric repeats in neuroblastoma: correlation with prognosis and other biological characteristics. Jpn J Cancer Res 83: 159-164, 1992.

35. Hiraga S, Ohnishi T, Izumoto S, Miyahara E, Kanemura Y, Matsumura $\mathrm{H}$ and Arita $\mathrm{N}$ : Telomerase activity and alterations in telomere length in human brain tumours. Cancer Res 58: 2117-2125, 1998 